\title{
Titanium compounds and their impact on the transformation of air pollutants
}

\author{
${ }^{1}$ Agnieszka Bok, ${ }^{2}$ Marta Bożym \\ ${ }^{1}$ Opole University of Technology, Faculty of Mechanical Engineering, Department of Manufacturing Engineering \\ and Automation; ul.S. Mikołajczyka 5, 45-271 Opole, Poland; e-mail: a.bok@doktorant.po.edu.pl \\ ${ }^{2}$ Opole University of Technology in Opole, Faculty of Mechanical Engineering, Department of Environmental Engineering; \\ ul. S. Mikołajczyka 5, 45-271 Opole, Poland; e-mail:m.bozym@po.opole.pl
}

(c) 2015 Authors. This is an open access publication, which can be used, distributed and reproduced in any medium according to the Creative Commons CC-BY 4.0 License requiring that the original work has been properly cited.

Received: 26 December 2014; accepted: 14 July 2015

\begin{abstract}
Titanium, as a transition metal, demonstrates a high mechanical strength. It is light and corrosion resistant. The estimation of the environmental impact of the use of machine parts that grains are freed from and contact the surface of titanium alloys by wear is buffing. Due to its catalytic action, $\mathrm{TiO}_{2}$ is nowadays added to asphalt, concrete, exterior paints for elevation, self-cleaning glass and protective coatings. It is also present in clothes, food (E171), cosmetics (CI 77891) and textiles. The research on the toxicity of titanium and its compounds points towards their neutral character, however an adverse impact is also observed in nature. $\mathrm{TiO}_{2} \mathrm{may}$ affect air quality. It promotes free radicals and ozone origination. The properties and direction of the use of titanium compounds and their influence on the circulation of pollutants are described below.
\end{abstract}

Keywords: titanium, $\mathrm{TiO}_{2}$, photo-catalysis, wear, pollutant, catalyst

\section{INTRODUCTION}

Titanium compounds occur in the natural environment at most as neutral minerals: rutile, anatase and brookite. These metals are treated as neutral for human health and for the environment. Moreover, they are used for the production of dental implants and orthopaedic limbs. There is no evidence of their toxic effects on living organisms. However, an increased accumulation of titanium compounds shows up in soil and water of polluted sites, i.e. airports.

Development of material technology is aimed, first and foremost, at achieving maximum product life span (LCA) by minimizing life cycle costs (LCC). Therefore, the application of titanium and its alloys in the production of machine parts is adapted to work at straitened conditions. Not only is the manufacturing process of highly durable coatings applied on the contact surface of tools used for making this structural material, but also everyday items are important. Titanium was and is still a relatively expensive material, but the financial issues are not that important in those cases in which desired advantages associated with its successful use make it an obvious choice. However 'successful' means relatively low confidence and high cost, not only because of the bare material costs. The point is that much effort had to be made due to its hard machinability. Rules of processing are still not sufficiently defined. Because production processes are fairly restricted, engineers have avoided the use of this material and have replaced it with others when possible. At present, there is a belief that titanium in non-military branches of industry has found permanent costumers. This should strengthen the economic basis of titanium metallurgy and facilitate the further expansion of titanium application in the $21^{\text {st }}$ century. 


\section{TYTANIUM AND ITS COMPOUNDS IN THE ENVIRONMENT}

The presence of titanium in the environment is closely associated with the development of material technologies for the maximization of product life cycles, discussed above. Human activity in this field is clearly present in paint pigments (titanium white; PW6 - Pigment White 6). The $\mathrm{TiO}_{2}$ pigment accounts for the largest use of titanium. Moreover, titanium and its alloys applied in aircraft and ship manufacturing show increasing relevance for the environment.

Titanium belongs to non-toxic metals in terms of living organisms. It doesn't belong to macro, or microelements (Twohy \& Gandrud 1998, Yaghoubi et al. 2000). The influence of titanium on plants depends on its concentration in their environment (air and soil). This metal can have a stimulating effect in certain doses. In case of its high concentration, it can act as a brake on the growth of plants (leading to chlorosis or slow growth) (Kuzel et al. 2003, McCullagh et al. 2012).

Titanium is a component of many minerals, notably oxides, titanates and silicates. It occurs primarily in the tetravalent state. The global average in soil has been estimated as $0.33 \%$ of titanium, although it is lower for podzols and histosols. Titanium has very low mobility under almost all environmental conditions (most conditions below a pH of 2) (Adams et al. 2008).

The rank of titanium minerals encloses the followings:

- ilmenite $\left(\mathrm{FeTi}_{3}\right)$,

- rutile $\left(\mathrm{TiO}_{2}\right)$,

- sphene $\left(\mathrm{CaTiSiO}_{5}\right)$,

- titanomagnetite $\left(\mathrm{Fe}_{2} \mathrm{TiO}_{4}\right)$.

In igneous rocks, the titanium concentration typically ranges from 300 (ultrabasic rocks) to $14,000 \mathrm{mg} \cdot \mathrm{kg}^{-1}$ (basalts). In sedimentary rocks, values range from $<400 \mathrm{mg} \cdot \mathrm{kg}^{-1}$ in pure carbonates to around $5000 \mathrm{mg} \cdot \mathrm{kg}^{-1}$ in shales. Generally, ultrafine particles containing titanium occur in association with clay fraction (Kabata-Pendias \& Pendias1999). Titanium minerals are usually preserved in soil. Their low solubility results in practically un-decomposed occurrence. The presence of Ti in surface marsh soil may amount up to $39 \% \mathrm{Ti}$, accompanied by $\mathrm{Fe}-\mathrm{Mn}$ concretions. $\mathrm{Fe}^{2+}$ ions may be absorbed on surfaces of Ti-minerals under reducing conditions. Subsequent oxidation to $\mathrm{Fe}^{3+}$ may lead to the formation of pseudorutile.

Another form of $\mathrm{TiO}_{2}$ - anatase - becomes toxic under the operation of ultraviolet radiation. It is damaging to the outer stratum of the epithelium through the output of free radicals, even with low values of UV levels.

Relatively little is known about the behaviour of titanium compounds in natural water. The low water solubility of titanium forms contributes to its low concentration in surface waters. Titanium exists only in a fully hydrated colloidal form, $\mathrm{TiO}(\mathrm{OH})_{2}$ (above $\mathrm{pH}$ of 2 ). The concentration of 'dissolved' Ti generally decreases with an increase in salinity. Titanium removal from water features flocculation of colloidal material, adsorption and scavenging by precipitation of $\mathrm{Mn}$ and Fe oxides. Consequently, Ti concentrations in natural water are generally as low as $1-3 \mu \mathrm{g} \mathrm{l} \mathrm{l}^{-1}$ (Adams et al. 2008).

\section{TITANIUM IN THE INDUSTRY}

Titanium belongs to transition metals. It shows high mechanical strength and corrosion-resistance, accompanied by light weight. Titanium is applied as a micro-alloying element to alloys of iron, aluminium, vanadium, molybdenum and others. For the most frequent applications of titanium in steel production, the metal increases the durability of steel of the maraging type. Emission of the described metal from this kind of material is extremely infinitesimal, as compared with the group concerned below. Structural materials made of titanium and its alloys are mainly used in the military, automotive and aircraft industries, as well as in medical engineering (dentures and orthopaedic). Long ago, titanium could hardly be considered as susceptible engineering material. This is no longer the case. As such, we can treat it now in a routine manner, like any other metal or alloy, not forgetting about its hard machinability. Whilst titanium may be expensive, many other corrosion resistant materials are not cheap either, and titanium-made equipment is by no means the most expensive of available alternatives.

At present, it is generally assumed, that imparting high strength to metal materials increases their resistance to plastic deformation. Highstrength materials also necessitate a certain level of toughness and plasticity. Alloy strength will 
increase, while the optimization of the amount of stabilizing elements in the alloys of supercritical composition promotes beta phase stabilization. As such, this process strengthens metals and simultaneously provides them with the capacity to be more effectively strengthened by heat treatment (Moiseev et al. 1982).

Abrasive titanium consumption leads to the decay of the topcoat, according to the definition of machine parts cooperatiion. The environmental impact of the removed particles of titanium alloys, wiped off during the use of vehicle engines (planes), is of importance.

The abrasive wear and tear is also conditioned by the hardness differential of cooperating parts, or, according to the definition of the abrasion process, when between rubbing surfaces, lose or confirmed particles of abradant exist. The occurrence of harsher material irregularities also causes micro-cutting, performing the function of microblades. Machining irregularities of oxidised products of wear and tear located in the area of rubbing also determine the process of wiping off. They move all over the surface of the contact zone as thin abradant (i.e. effect of scuffing). The mechanical properties of material determined by abrasion are expressed through the scale of depicted height or mass loss on the surface area unit of a tested sample. The speed of the abrasive wear depends on material parameters, inter alia on its chemical composition and hardness of abradant particles working in the friction zone. In addition, processing conditions, such as the geometrical parameters and the mutual speed value of parts rubbing themselves are essential.

Titanium has a big affinity to oxygen, therefore on its surface or on the top of materials containing titanium, usually a protective, corrosion resistant layer of titanium oxides is formed. Titanium dioxide(IV), $\mathrm{TiO}_{2}$ is the most universal and most long-lasting titanium oxide. It displays $s$ amphoteric properties. This oxide reacts with concentrated $\mathrm{H}_{2} \mathrm{SO}_{4}$. In the case of alloying with carbonates or oxides of other metals, it changes into titanates.

Parts of mechanical devices, such as jet engines, can cause emission of dust consisted of metal oxides. As a result, oxidation of titanic dusts to $\mathrm{TiO}_{2}$ and its photocatalytic action in the air are possible. Those kinds of elements often exist in high temperature conditions. Thermal conditions present in these arrangements support oxidation processes in the top-layer-area. Products of surface layer oxidation demonstrate hardness and, finally, serve as abradants, according to the forces governing the working system. The hardness of $\mathrm{TiO}_{2}$ is estimated at 6 in the hardness scale of minerals (by Mohs). That same mineral susceptibility responds to tool steel.

When the not-oxidized titanic area comes in contact with liquefied oxygen, an inflammation may take place. This reaction can start as a result of stroking by a hard object or through a material crack, caused by mechanical deformation. This property of titanium explains why the application of dedicated alloys of titanium or titanic elements is coated with protective layers. Those coatings show unusual resistance for abrasive wear. They also perform strengthening functions for structures in aviation and space technology. This is the matter used for controlling and limiting the parameters caused by hydrogenation, exhibition to oxygen, nitrogen and carbon saturation. Those processes affect directly the degree of the brittleness of the surface. Titanium alloys are widely used in aerospace applications, due to their properties such as the high strength to weight ratio, good corrosion and creep resistance. Low wear resistance of these alloys limits their use in tribological applications. Abrasive wear of the surface layer of any metal part is smaller in the case when the arrangement is working on a permanent basis - under constant thermal conditions. A relation on exposing contact surfaces of the set-up parts to the wear and tear of technological processes of strengthening is meant. These are conducted during final product processing. There are techniques recognized as effective solutions in surface engineering to make light weight, high strength alloys more suitable for general engineering applications (Reddy et al. 2013).

Effective methods for increasing the wear resistance of titanium and its alloys include cementation, boriding, nitriding, chromizing, chrom-siliciding, hydriding and oxidizing. Those processes improve the contact surface by thermal or thermochemical treatment. Thermodiffusional saturation with carbon, nitrogen, boron, enables them to become very hard and wear-resistant layers on the surface of titanium alloys (Petrova 2002). 


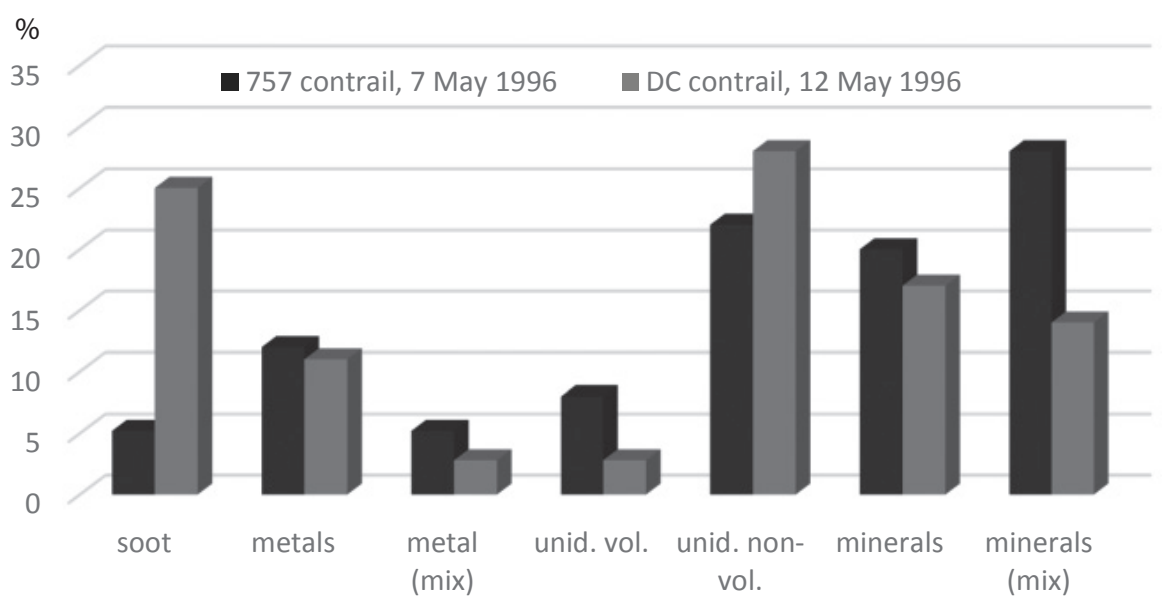

Fig. 1. Bar chart showing percentages of various residual particle types observed in the 757 and DC-8 contrails (Twohy \& Gandrud 1998)

Development of the thermal spraying technology allowed the application of as the Thermal of Coatings Barriers (TBC). Trial runs have been carried out on the application of TBC on spatulas of the turbine of a J-75 engine. An increase in the effectiveness of the turbines was recorded. The use of TBC has massively lowered (about $175^{\circ} \mathrm{C}$ ) the temperature of the ground and provided an increase in the operating time, thus lowering the abrasive wear and tear and the emission of dusts containing titanium (Sosnowy et al. 2013).

The monitoring of part connection zones and joins of materials should be considered, when titanium compounds emission is discussed. Titanium belongs to elements present in alloys, applied in the production of aero engines that emit onthe-fly dusts, when metal elements are wiped off. The potential importance of particles in aircraft exhaust for atmospheric chemistry has been explored in experiments focused on plume and contrail formation and evolution. The study of contrails and their importance as a kind of aircraft exhaust have been carried out in an experiment (Twohy \& Gandrud 1998).Two contrail cases were compared: a sample generated by the 757 aircraft (Boeing type) on 7 May 1996 and other specimen generated by the DC- 8 on 12 May. Average ambient temperatures and pressures, as well as other weather conditions were comparable. Residual particles, larger than $0.1 \mu \mathrm{m}$, were analyzed by electron microscopy. Figure 1 presents the percentage of particle types of substances recognized in the analyzed samples. Substances such as soot, metals, and volatile organic substances were identified. The percentages of particle types in analyzed samples were roughly equal (Twohy \& Gandrud 1998).

While soot was identified by its morphology, metals are understood as a mixture of $\mathrm{Fe} / \mathrm{Cr}$ or Ti. The average of the $\mathrm{Fe}, \mathrm{Cr}$ and Ti mixture content amounts to about 3\%. "Mix" means sulphur was also present in the samples. Under minerals were predominately $\mathrm{Ca}$, but also $\mathrm{Na}, \mathrm{A} 1, \mathrm{~K}$, and/or Fe. Non-volatiles concerned silicates or soot. Some volatiles contained carbon; therefor many of the unidentified volatile particles are suggested to be organic compounds (Twohy \& Gandrud 1998).

The presence of metal oxides in the vapour samples is logical and results from constructional materials applied in jet engines of inspected planes. Iron and chromium are alloying elements obvious for the use of getting acid-resistant steel used in a combustion chamber. The presence of titanium is the effect of implementing parts resistant in conditions of high temperatures, prevailing in turbines.

The dust contains titanium and other metals. After falling on the earth's surface, it can pollute the soil and surface waters. As such it can be taken up by plants and get in the food chain of animals. The daily intake of titanium within a twenty four hour period - contained in drinking water - acceptable for humans is maximally $5 \mu \mathrm{g}$. The exposure ton titanium occurs by food consumption, mainly eggs and dairy products. $\mathrm{TiO}_{2}$ is also put in some cheese, to precipitate ripening and for conservation. It has been estimated that Americans, with food consumption, were exposed to about 
$300-400 \mu \mathrm{g}$ Ti per day, while the British up till $800 \mu \mathrm{g}$ Ti. However, it has been established that human organism may absorb Ti only up to $3 \%$ of the supplied dose (Szuliński \& Strusiński 2001). The amount of daily Ti intake by human organism depends on eating habits and, on the presence of pollutant sources in the given area. The Ti-consisted pollutants mostly originate from industry, airports and incinerators of waste pollutants.

\section{IMPACT OF TITANIUM COMPOUNDS ON THE TRANSFORMATION OF AIR POLLUTANTS}

Titanium dioxide, as a photocatalyst, results in photochemical processes, or the origination of radical hydroxyls, that are reactive and not selectively active oxidants of pollutants. While the reaction ROS, reactive oxygen species (including $\mathrm{O}_{2}, \mathrm{H}_{2} \mathrm{O}_{2}$, singlet oxygen, $\mathrm{OH}$ ) comes into existence (MAK Value Documentation, 2012). The mechanism describing the reaction is presented in Figure 2.

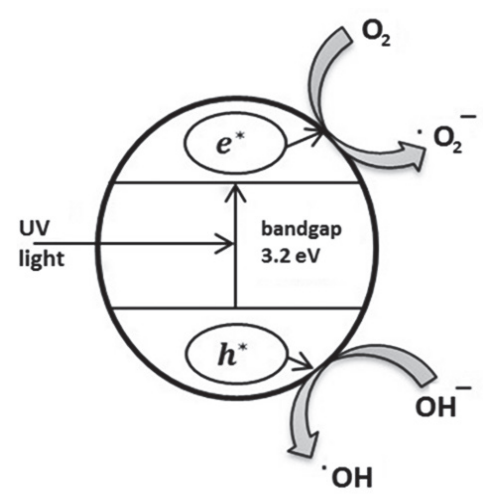

Fig. 2. The mechanism of the $\mathrm{TiO}_{2}$-doped reaction taking place due to the stability and low energy band-gap (Rizzo 2009)

The illumination of $\mathrm{TiO}_{2}$ closely with UV radiation $(\lambda<400 \mathrm{~nm})$ generates electron-hole pairs $\left(\mathrm{e}^{-} / \mathrm{h}^{+}\right)$. This process limits the creation of oxidizing species (i.e. $\bullet \mathrm{OH}$ radicals). $\mathrm{TiO}_{2}$ is evaluated to be one of the most suitable semiconductors for this type of process (Rizzo 2009).

To begin with, information about the catalytic photoactivity of titanium oxide(IV) is noted by Keidel, in a publication from 1929 (Höhr et al. 2002). In 1972, an electrode made from $\mathrm{TiO}_{2}$ was used for photoelectrochemical decomposition of water. Reduction of cyanide-ions was being examined in irradiated $\mathrm{TiO}_{2}$ suspension (Górska 2009). Further research of the so-called heterogeneous photocatalysis by $\mathrm{TiO}_{2}$ relied on the use of this substance for decomposing environmental pollutions (Górska 2009, Ramirez et al. 2010). At present, the possibility of applying the heterogeneous photocatalysis using $\mathrm{TiO}_{2}$ is being used to eliminate organic pollutants from air, water and sewers (Hoffmann et al. 1995, Wang et al. 1999, Frazer 2001, Ao et al. 2003, Devahasdin et al. 2003) and in the processes of self-purification of surfaces (Wang et al. 1999, Giergiczny \& Sokołowski 2009, Langridge et al. 2009).

Antibacterial action is an additional asset of the catalytic $\mathrm{TiO}_{2}$ photoactivity, both in the air, as well as in the water (Bekbölet 1997, Gelover et al. 2006, Rizzo 2009), even though antibacterial $\mathrm{TiO}_{2}$ action is weaker than processes using alcohol or formulations containing chlorine. In fact, titanium compounds are less toxic to the environment and act longer. Antibacterial action is based on the occurrence of free radicals under the influence of UV radiation. To increase the effectiveness of antibacterial action, it is possible to join $\mathrm{TiO}_{2}$ with other antibacterial substances, like colloidal silver, compounds of metals or organic compounds (Cheng et al. 2006, Skorb et al. 2008, Gao et al. 2012). Due to its septic qualities, $\mathrm{TiO}_{2}$ application is more and more universal in the production of apparel and "breathing fabrics". The folded technologically, modern, polyester fabric subjected by $\mathrm{TiO}_{2}$ in double-sided alteration, has the property of actively expelling water - exclusively in one direction. However, it turns out that $\mathrm{TiO}_{2}$ nanoparticles may break away while wiping off the surface or clothes. Functional textiles rank high, since they are often worn in direct contact with the skin. Engineered Nanoparticles (ENP) for antimicrobial activity or UV protection are both: Ag- and $\mathrm{TiO}_{2}$-ENP. ENP can release nano objects that may be taken up from textiles by ingestion, or by inhalation. For adults, the external exposure to compounds contained in fabrics is of importance. For children, the oral pathway may also play a role, but otherwise, they release less sweat that could mobilize ENP from the textiles. The external dermal exposure to substances in textiles has not yet been examined precisely. An investigation of $\mathrm{TiO}_{2}$-doped textiles, after a strictly determined 
number of washing cycles with washing detergent (artificial sweat), has shown that research objects released $\mathrm{TiO}_{2}$ below the limit of detection. So repeated wearing (and sweating) will not result in $\mathrm{TiO}_{2}$ release, $\mathrm{TiO}_{2}$ particle is firmly incorporated into the fibre. For $\mathrm{TiO}_{2}$ in products like creams and sunscreens, it was determine that the dermal exposure was larger than for textiles. One single event of sunscreen use produces an amount of ca. $1000 \mathrm{mg}$. As such, the $\mathrm{TiO}_{2}$ intake in textiles is far less than sunscreen (Von Goetz et al. 2013).This may have a negative influence on human health.

Another case where $\mathrm{TiO}_{2}$ is being used is as a mineral dye in food manufacturing (E171). As mentioned before, it is also used in cheese-making and as a filler of medicine. It is often applied in the production of hygienic cosmetic products, due to its antibacterial properties. The use of two mineral forms of $\mathrm{TiO}_{2}$ (anatase and rutile), added to creams as mineral filters against UV radiation, brings some doubt. Their mixture is marked by the symbol: C.I. 77891. According to the ranking of the Colour Index International, these belong to the group of inorganic pigments. These minerals remaining on the skin can cause damage to the outer stratum of the epithelium, as a result of free radical activation with UV light. This can be avoided by washing the skin accurately. Vitamin $\mathrm{E}$ and $\mathrm{C}$ are also actively degraded by the presence of $\mathrm{TiO}_{2}$ in the emulsion during solar exposure. This effect is reversed with $\mathrm{TiO}_{2}$ doped by manganese that can protect $>90 \%$ of anti-oxidants in both the oil and water phases of the cosmetics. The minimization of surface scavenging by ROS occurs due to the fact that manganese is responsible for the significantly reduced ROS load on the organic components and photo-stabilization of emulsions (Wakefield \& Stott 2006).

The fall of the content of pollutants, as a result of the $\mathrm{TiO}_{2}$ operation under the influence of UV radiation, usually occurs in environmental temperatures and at atmospheric pressure. Heterogeneous photocatalysis allows the disintegration of organic compounds present in air, waters or sewers to $\mathrm{CO}_{2}$, water and inorganic acids (Hager \& Bauer 1999, Herrmann 1999, Wang et al. 1999, Frazer 2001). Many examples of catalytic $\mathrm{TiO}_{2}$ working on the decomposition of organic compounds, i. e. benzene, toluene or BTEX sums, acetic aldehyde, acetone, phenol, formaldehyde, alcohol gly- cols, organic acids or organic dyes so as methylene blue, Reactive of Roadsteads, Direct Green 99, Acid Orange 7 and others were described in literature (Hager \& Bauer 1999, Asahi et al. 2001, Ao et al. 2003, Strini et al. 2005 and 2013, Górska 2009, Liu et al. 2014a, 2014b). The impact of $\mathrm{TiO}_{2}$ involves the process of decomposition of PAHs, such that simpler organic compounds are formed. Those products are often more toxic than the decomposed organic pollutants.

Nitrogen-doped titanate nanotubes obtained via hydrothermal treatment of anatase powder in restricted conditions are tested and modified with the aim to use electrode materials in photocatalytic oxidation of organic pollutants (Souza et al. 2014). In addition, the titanate/ $\mathrm{Au} @ \mathrm{TiO}_{2}$ hollow hybrid is investigated in the enhancement of photocatalytic activity by matching energy compounds that may lower the recombination rate of electron-hole pairs and eventually improve the photocatalytic activity. The titanate/Au@TiO 2 photocatalyst may find potential application in photocatalysis (Liu et al. 2014a, 2014b).

Photo-reactors for industrial applications need to meet the challenge of capacity, reliability and ease of use. $\mathrm{TiO}_{2}$ catalyst may occur in a photoreactor in one of three forms. It may occur as a $\mathrm{TiO}_{2}$ suspension, or as a wall coating consisted of $\mathrm{TiO}_{2}$ film. Otherwise it could be a fixed bed, composed of $\mathrm{TiO}_{2}$ glass rings (Adams et al. 2008). Currently, the only design of a photo-reactor which is capable of processing the level of wastewater required is that of suspension reactors. However, their application is a matter of discussion. Moreover, the application of semiconductors in photocatalysis for remediation has real scope for impacting water pollution and, hence, global water scarcity (McCullagh et al. 2011). Adams et al. (2008) have reported the comparison of a standard flat plate reactor with a novel drum reactor (Robertson et al. 2004) for the removal of organic (oil and gas hydrocarbons) contaminants from the water. The drum reactor concept was a single pass continuous flow system. The treatment of wastewater has relied on a new attempt to put the contaminated liquid upon rotating paddles to ensure an even distribution of catalyst. In a bid to develop a reactor deemed more environmentally friendly, pelletized catalyst was used to reduce downstream processing restrictions associated with the filtration 
of powdered catalyst. The design mentioned above has proven effectiveness in the removal of hydrocarbons. The drum reactor achieved $90 \%$ removal in less than 10 minutes. Such a high level of reduction over a short period of time is attributed to samples passing through 3 consecutive drums, each with $200 \mathrm{~g}$ of $\mathrm{TiO}_{2}$ catalyst present. Therefore, $600 \mathrm{~g}$ of catalyst are utilized for the entire system (Adams et al. 2008, McCullagh et al. 2011). It is important to understand that there is no sense in applying these kinds of catalysts in doses exceeding those confirmed effective by research. Any particle of $\mathrm{TiO}_{2}$ catalyst must have direct UV light approach assured, to achieve the maximal load capability. In order to reduce the cost of the disintegration of pollutants, it is possible to apply solar power as a UV radiation source and to use the atmospheric air as the source of oxygen (Anpo 2000, Asahi et al. 2001).

What is more, $\mathrm{TiO}_{2}$ catalysts are being used for the decomposition of nitrogen oxides in the air (Dalton et al. 2002, Ao et al. 2003, Maggos et al. $2007,2008)$. This effect is achieved by the addition of $\mathrm{TiO}_{2}$ to exterior house paint, building materials or self-cleaning plate glass (Langridge et al. 2009, O'Keeffe et al. 2013).The reduction of harmful $\mathrm{NO}_{x}$ produced by vehicles and in industry is an example of catalytic $\mathrm{TiO}_{2}$ action. The substantial issue is that, due to the increase in traffic, nitrogen oxide concentration has grown. $\mathrm{NO}_{\mathrm{x}}$ are coming into existence as a source of ozone synthesis. Ozone, $\mathrm{O}_{3}$, as the active principle of the municipal smog (Californian type) negatively influences human health.

The principle of the operation of ( $\left.{ }^{\circ} \mathrm{OH}\right)$, in the presence of $\mathrm{TiO}_{2}$ takes the form (1) and (2) (Giergiczny \& Sokołowski 2009):

$$
\begin{gathered}
\mathrm{NO}+2 \mathrm{OH}^{-} \rightarrow \mathrm{NO}_{2}+\mathrm{H}_{2} \mathrm{O} \\
\mathrm{NO}_{2}+\mathrm{OH}^{-} \rightarrow \mathrm{NO}_{3}^{-}+\mathrm{H}^{+}
\end{gathered}
$$

Formulae (1) concerns the oxidation of nitrogen monoxide(II) to the nitrogen dioxide(IV). Reaction (2) presents the reduction of $\mathrm{NO}_{2}$ to the $\mathrm{NO}_{3}{ }^{-}$nitrate ion.

The nitric acid origination (that occurs with the reduction of NOx) can negatively affect the environment. A solution of $\mathrm{TiO}_{2}$ can be applied in the form of an additive in building materials. The alkaline character of the building materials causes the neutralization of nitric acid by creating salts (nitrates), which can be leached by precipitation (Giergiczny \& Sokołowski 2009).

It is doubtful, whether the application of technologies for doping structural materials with titanium dioxide causes health hazards. There is currently no research on long-term effects of these kinds of additives. $\mathrm{TiO}_{2}$ is usually mixed up in form of nanomolecules with cement, which can turn out to be harmful if inhaled by lungs, i.e. during the abrasion of the top layer of the building materials. The harmfulness of the nanoparticles is difficult to determine, because it depends heavily on many factors, i.e. nanoparticles size and shape. On the other hand, the choice of nanomolecules production technology and chemicals during processing is of importance, because some of the arising substances may remain on the surface.

Titanium dioxide is a substance, whose excitation state has a short lifespan (ns to $\mu$ s). These particles are taken up by inhalation or orally. Titanium dioxide particles applied to the skin penetrate only as far as the outer layer of the stratum corneum. In the lungs, titanium dioxide particles can accumulate and impair the clearance function. There is no evidence to suggest that Ti performs any necessary role in the human organism. In spite of the fact that in living creatures its absorption is weak and retention low, titanium is considered to be a non-toxic substance. At present, no evidence suggests a negative effect of titanium and its compounds on the human health.

On the one hand, the $\mathrm{TiO}_{2}$ addition to water has affirmed a positive effect on the survivability, reproduction and a weight-loss of laboratory animals. Reactions caused by $\mathrm{TiO}_{2}$ in the lungs after inhalation does not occur for long. In animal studies, after repeated inhalation, inflammatory reactions, fibrosis and lung tumours were observed (MAK Value Documentation, 2012). ROS particles cause oxidative DNA damage (adducts of DNA breaks), which, unless accurately repaired, result in mutations during stimulated cell spread. Such mutations may lead to the spread of disease by bacteria and can be accompanied by complications. Nowadays, humans have discovered many, but not all, vaccines against many illnesses. Common use of protective means, even clothes, may activate mutation processes by bacteria, so that an increase in drug resistance will heavily deteriorate daily life. Current solutions being used in case 
of influenza, mumps or chickenpox would not work any longer, and many "forgotten diseases" may break out and arise as new huge civilization disasters.

The steady influence of genotoxic oxygen and nitrogen species ultimately leads to uncontrolled growth in the pulmonary epithelia. There is evidence showing that the surface coating of fine and ultrafine titanium dioxide particles can cause negative effects (Höhr et al. 2002, WHO 2010). It is also claimed, that $\mathrm{Ti}$ can be accumulated in the brain, going through the blood-brain barrier, but evidence of the adverse impact for the central nervous system was not reported (Szuliński \& Strusiński 2001). The toxic impact on humans of titanium and its gaseous compounds was not confirmed, in implants applied, which are based on this material (Koller et al. 2007).

\section{CONCLUSIONS}

Different sources of titanium compounds provide a diversity of forms, their occurrence and properties. Titanium and its compounds are split up, due to their generation, into two groups: natural (mineral) and antrophogenic (industrial) sources. Titanium is a component of many minerals. Compounds of titanium, especially $\mathrm{TiO}_{2}$, are being used as pigment in the dyeing industry and as catalysts of chemical reactions. Due to the catalysing properties of reduction in nitric oxides, $\mathrm{TiO}_{2}$ is used as an additive in asphalt surfaces, concrete, mortars (Park 2014) and exterior paint. Titanium compounds emitted by anthropogenic point sources are understood as pollutants.

On the one hand, Ti shows high effectiveness as an antibacterial substance. Due to this property $\mathrm{TiO}_{2}$ is being used as a mineral dye in food manufacturing (E171) and as medicine filler. As a component of cosmetics, it protects human skin from UV rays, present in the visible spectrum humans are subjected to daily. Its value is also the result of the short lifespan of the excitation state. Compounds consisting of titanium may affect living creature differently, depending on the type of intake. In paper inhalation, or orally, the external use of $\mathrm{TiO}_{2}$ is of concern. There is no possibility that ROS will cause hazardous reactions in the lungs after inhalation. In general, titanium compounds are claimed to be non-toxic. What is more, they have a proven weak absorption and low retention in living organisms.

On the other hand:

- the nitric acid originated in the process of $\mathrm{NOx}$ reduction can produce adverse environmental effects,

- titanium compounds cause damage to the epithelium and mutations of macro-systems (organs) and microorganisms,

- long-time exposure to higher doses of titanium compounds results in disease in plants (chlorosis) and animals (respiratory system disease).

Technological solutions using titanium compounds are characterized by longer life cycles when compared to manufacturing in conventional technology. As such, the consolidation for knowhow expansion in titanium metallurgy is determined by its various purposes. Hence, in spite of few aforementioned disadvantages of titanium compounds, it is increasingly used in production of everyday objects. This can save resources, in accordance with the Best Available Technique (BAT) regulation. BAT aims to use "reasonably achievable", "best practicable" and "best available" production techniques. Although the cost of the achieved product is increasing, as a result of implementation of advanced technology and new materials, this price-growth is hardly noticeable to the user. The increase in demand from consumers shows that the change can lead to new expectations and trends by the community. The support given by the selection of a new generation of products means simultaneous consent to conduct rational economic choices. This is expressed inter alia through the reduction in utilization processes and by a decrease in the use of more harmful, both for consumers and the environment, protective paint coatings.

This paper presents the properties of titanium compounds, the effects of its use and the impact on the environment quality and human health. $\mathrm{TiO}_{2}$ nanoparticles release i.e. during abrasion of surfaces or clothes, can have negative consequences on the respiratory system. Meanwhile, materials enriched with titanium dioxide are becoming more and more common. There are actually no studies on the long-term effects of their use. Toxicity study of titanium and its compounds indicate their neutral character. However, this catalyst of nitric 
oxides reduction is applicable universally. Possibilities of any negative effects on health and on the environment are often mentioned. The challenge is to determine the virtual impact of titanium compounds on the environment. The review shows, that it is necessary to conduct wide research of the described areas of titanium compound use and on the long-term effects of applying them.

\section{REFERENCES}

Adams M., Campbell I. \& Robertson P.K.J., 2008. Novel photocatalytic reactor development for removal of hydrocarbons from water. International Journal of Photoenergy, ID 674537, 1-7.

Anpo M., 2000. Utilization of $\mathrm{TiO}_{2}$ photocatalysts in green chemistry. Pure and Applied Chemistry, 72, 1787-1792.

Ao C.H., Lee S.C., Mak C.L. \& Chan L.Y., 2003. Photodegradation of volatile organic compounds (VOCs) and NO for indoor air purification using $\mathrm{TiO}_{2}$ : promotion versus inhibition effect of NO. Applied Catalysis B-Environmental, 42, 2, 119-129.

Asahi R., Morikawa T., Ohwaki T., Aoki K. \& Taga Y. 2001. Visible-light photocatalysis in nitrogen-doped titanium oxides. Science, 293, 269-271.

Bekbölet M., 1997. Photocatalytic bactericidal activity of $\mathrm{TiO}_{2}$ in aqueous suspensions of E. coli. Water Science and Technology, 35, 11-12, 95-100.

Cheng Q., Li C., Pavlinek V., Saha P. \& Wang H., 2006. Surface-modified antibacterial $\mathrm{TiO}_{2} / \mathrm{Ag}^{+}$nanoparticles: Preparation and properties. Applied Surface Science, 252, 4154-4160.

Dalton J.S., Janes P.A., Jones N.G., Nicholson J.A., Hallam K.R. \& Allen G.C., 2002. Photocatalytic oxidation of NOx gases using $\mathrm{TiO}_{2}$ : a surface spectroscopic approach. Environmental Pollution, 120, 2, 415-422.

Devahasdin S., Fan C., Li K.Y. \& Chen D.H., 2003. $\mathrm{TiO}_{2}$ photocatalytic oxidation of nitric oxide: transient behaviour and reaction kinetics. Journal of Photochemistry and Photobiology A: Chemistry, 156, 161-170.

Frazer L., 2001. Titanium dioxide: Environmental white knight? Environmental Health Perspectives, 109, 4, A174-A177.

Gao P., Liu J., Zhang T., Sun D.D. \& Ng W., 2012. Hierarchical $\mathrm{TiO}_{2} / \mathrm{CdS}$ "spindle-like" composite with high photodegradation and antibacterial capability under visible light irradiation. Journal of Hazardous Materials, 229-230, 209-216.

Gelover S., Gómez L.A., Reyes K. \& Leal M.T., 2006. A practical demonstration of water disinfection using $\mathrm{TiO}_{2}$ films and sunlight. Water Research, 40, 3274-3280.

Giergiczny Z. \& Sokołowski M., 2009. Fotokatalityczne właściwości betonu zawierającego cement Tiocem. [in:] Tic J.W. (red.), Nowe inicjatywy organizacyjne i technologiczne $w$ zakresie chemii przemysłowej, Akademicki Inkubator Przedsiębiorczości Politechnika Opolska, Opole, $123,73-82$.

Górska P., 2009. Preparatyka i badania katalizatorów tytanowych aktywnych $w$ świetle widzialnym. Politechnika Gdańska, Gdańsk [doctoral thesis].
Hager S. \& Bauer R., 1999. Heterogeneous photocatalytic oxidation of organics for air purification by near UV irradiated titanium dioxide. Chemosphere, 38, 7, 1549-1559.

Herrmann J.M., 1999. Heterogeneous photocatalysis: fundamentals and applications to the removal of various types of aqueous pollutants. Catalysis Today, 53, 115-129.

Hoffmann M.R., Martin S.T., Choi W. \& Bahnemann D.W., 1995. Environmental applications of semiconductor photocatalysis. Chemical Reviews, 95, 69-96.

Höhr D., Steinfartz Y., Schins R.P.F., Knaapen A.M., Matra G., Fubini B. \& Bonn P.J.A., 2002. The surface area rather than the surface coating determines the acute inflammatory response after instillation of fine and ultrafine $\mathrm{TiO}_{2}$ in the rat. International Journal of Hygiene and Environmental Health, 205, 239-244.

Ihara T., Miyoshi M., Iriyama Y., Matsumoto O. \& Sugihara S., 2003. Visible-light-active titanium oxide photocatalyst realized by an oxygen-deficient structure and by nitrogen doping. Applied Catalysis B: Environmental, 42, 403-409.

Kabata-Pendias A. \& Pendias H., 1999. Biogeochemia pierwiastków śladowych. Wyd. Nauk. PWN, Warszawa.

Koller G., Cook R.J., Thompson I.D., Watson T.F. \& Di Silvio L., 2007. Surface modification of titanium implants using bioactive glasses with air abrasion technologies. Journal of Materials Science: Materials in Medicine, 18, 2291-2296.

Kuzel S., Hruby M., Cígler P., Tlustos P. \& Van P.N., 2003. Mechanism of physiological effects of titanium leaf sprays on plants grown on soil. Biological Trace Element Research, 91, 179-189.

Langridge J.M., Gustafsson R.J., Griffiths P.T., Cox R.A., Lambert R.M. \& Jones R.L., 2009. Solar driven nitrous acid formation on building material surfaces containing titanium dioxide: A concern for air quality in urban areas? Atmospheric Environment, 43, 5128-5131.

Liu L., Yang J., Liu S., Bai L., Liua B., Wang Q., Xua G., Jinga P., Yu S. \& Zhang J., 2014a. Hollow hybrid titanate/Au@ $\mathrm{TiO}_{2}$ hierarchical architecture for highly efficient photocatalytic application. Catalysis Communications, 54, 66-71.

Liu Y., Xu H., Zhu S., Zhou M. \& Miao J., 2014b. Enhanced Degradation of Acid Orange 7 Solution by Non-thermal Plasma Discharge with $\mathrm{TiO}_{2}$. Plasma Chemistry and Plasma Processing, 34, 1403-1413.

Maggos T., Bartzis J.G., Leva P. \& Kotzias D., 2007. Application of photocatalytic technology for NOx removal. Applied Physics A: Materials Science \& Processing, 89, 1, 81-84.

Maggos T., Plassais A., Bartzis J.G., Vasilakos C., Moussiopoulos N. \& Bonafous L., 2008. Photocatalytic degradation of NOx in a pilot street canyon configuration using $\mathrm{TiO}_{2}$ mortar panels. Environmental Monitoring and Assessment, 136, 1-3, 35-44.

MAK Value Documentation, 2012. Allgemeiner Staubgrenzwert (A-Fraktion) (Granuläre biobeständige Stäube (GBS)). The MAK-Collection for Occupational Health and Safety, 1-78.

McCullagh K., Skillen N., Adams M. \& Robertson P.K.J., 2011. Photocatalytic reactors for environmental remediation: a review. Journal of Chemical Technology and Biotechnology, 86, 1002-1017. 
Moiseev V.N., Zakharov Yu.I. \& Znamenskaya E.V., 1982. Trends in the development of high-strength titanium alloys. [in:] Williams J.C. \& Belov A.F. (eds), Titanium and Its Alloys. Scientific and Technological Aspects. Volume 3, Springer US, 2101-2110.

O'Keeffe C., Gannon P., Gilson P., Kafizas A., Parkin I.P. \& Binions R., 2013. Air purification by heterogeneous photocatalytic oxidation with multi-doped thin film titanium dioxide. Thin Solid Films, 537, 131-136.

Park S.M., Chekli L., Kim J.B., Shahid M., Shon H.K., Kim P.S., Lee W.S., Lee W.E., Kim J.H., 2014. NOx removal of mortar mixed with titania produced from Ti-salt flocculated sludge. Journal of Industrial and Engineering Chemistry, 20, 3851-3856.

Petrova A.M., 2002. Structural wear-resistant sintered materials based on titanium. Powder Metallurgy and Metal Ceramics, 41, 7-8.

Ramirez A.M., Demeestere K., De Belie N., Mantyla T., Levanen E., 2010. Titanium dioxide coated cementitious materials for air purifying purposes: Preparation, characterization and toluene removal potential. Building and Environment, 45, 832-838.

Reddy G. Madhusudhan, Rao A. Sambasiva \& Rao K. Srinivasa, 2013. Friction Stir Surfacing Route: Effective Strategy for the Enhancement of Wear Resistance of Titanium Alloy. Transactions of the Indian Institute of $\mathrm{Me}$ tals, 66, 3, 231-238.

Rizzo L., 2009. Inactivation and injury of total coli form bacteria after primary disinfection of drinking water by $\mathrm{TiO}_{2}$ photocatalysis. Journal of Hazardous Materials, $165,48-51$.

Robertson P.K.J., Campbell I. \& Russell D., 2004. International Patent Publication. Photocatalytic Reactor - Apparatus and Method for Treating Fluid by Means of a Treatment Container. Number WO 2005/033016.

Skorb E.V., Antonouskaya L.I., Belyasova N.A., Shchukin D.G., Mohwald H. \& Sviridov D.V., 2008. Antibacterial activity of thin-film photocatalysts based on metal-modified $\mathrm{TiO}_{2}$ and $\mathrm{TiO}_{2}: \mathrm{In}_{2} \mathrm{O}_{3}$ nanocomposite. Applied $\mathrm{Ca}$ talysis B: Environmental, 84, 94-99.

Sosnowy P., Swadźb L., Jurczak M., Witala B. \& Supernak W., 2013. Wybrane właściwości powłok TBC wytwarzanych metoda Triplex Pro $200 \mathrm{z}$ otworami wycinanymi laserem. Hutnictwo, Górnictwo, Inżynieria Materiałowa, 34, $5,542-546$

Souzaa J.S., Krambrock K., Pinheirob M.V.B., Andoc R.A., Guhad S. \& Alvesa W.A., 2014. Visible-light photoca- talytic activity of $\mathrm{NH}_{4} \mathrm{NO}_{3}$ ion-exchanged nitrogen-doped titanate and $\mathrm{TiO}_{2}$ nanotubes. Journal of Molecular Catalysis A: Chemical, 394, 48-56.

Strini A., Cassese S. \& Schiavi L., 2005. Measurement of benzene, toluene, ethylbenzene and oxylene gas photodegradation by titanium dioxide dispersed in cementitious materials using a mixed flow reactor. Applied Catalysis B: Environmental, 61, 90-107.

Strini A., Sanson A., Mercadelli E., Sangiorgi A. \& Schiavi L., 2013. Low irradiance photocatalytic degradation of toluene in air by screen-printed titanium dioxide layers. Thin Solid Films, 545, 537-542.

Szuliński S. \& Strusiński A., 2001. Plastyczność pamięciowa mózgu białych szczurównarażonych długookresowo na tytan w wodzie do picia. Roczniki Państwowego Zakładu Higieny, 52, 1, 35-39.

Twohy C.H. \& Gandrud B.W., 1998. Electron microscope analysis of residual particles from aircraft contrails. Geophysical Research Letters, 25, 9, 1359-1362.

Von Goetz N., Lorenz C., Windler L., Nowack B., Heuberger M. \& Hungerbuehler K., 2013. Migration of $\mathrm{Ag}^{-}$ and $\mathrm{TiO}_{2}^{-}$(nano)particles from Textiles into Artificial Sweat under Physical Stress: Experiments and Exposure Modeling. Environmental Science \& Technology, 47, 9979-9987.

Wakefield G. \& Stott J., 2006. Photostabilization of organic UV-absorbing and anti-oxidant cosmetic components in formulations containing micronized manganesedoped titanium oxide. Journal of Cosmetic Science, 57, 385-395.

Wang K.H., Hsieh I.H., Ko R.C. \& Chang C.Y., 1999. Photocatalytic degradation of wastewater from manufactured fiber by titanium dioxide suspensions in aqueous solution. Environment International, 25, 5, 671-676.

Wang H., Wu Z., Zhao W. \& Guan B., 2007. Photocatalytic oxidation of nitrogen oxides using $\mathrm{TiO}_{2}$ loading on woven glass fabric. Chemosphere, 66, 185-190.

World Health Organization, International Agency for Research on Cancer, 2010. Titanium dioxide. [in:] IARC Monographs on the Evaluation of Carcinogenic Risks to Humans. Volume 93: Carbon Black, Titanium Dioxide, and Talc, WHO International Agency for Research on Cancer, Lyon, 193-276.

Yaghoubi S., Schwietert Ch.W. \& McCue J.P., 2000. Biological roles of titanium. Biological Trace Element Research, $78,205-217$. 